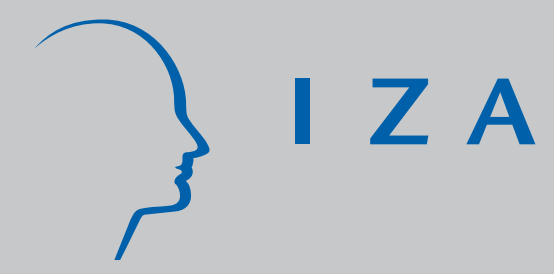

IZA DP No. 2394

The Nonlinear Link between Height and Wages: An Empirical Investigation

Olaf Hübler

October 2006 


\title{
The Nonlinear Link between Height and Wages: An Empirical Investigation
}

\author{
Olaf Hübler \\ University of Hannover, \\ IAB Nürnberg and IZA Bonn
}

Discussion Paper No. 2394

October 2006

\author{
IZA \\ P.O. Box 7240 \\ 53072 Bonn \\ Germany \\ Phone: +49-228-3894-0 \\ Fax: +49-228-3894-180 \\ E-mail: iza@iza.org
}

\begin{abstract}
Any opinions expressed here are those of the author(s) and not those of the institute. Research disseminated by IZA may include views on policy, but the institute itself takes no institutional policy positions.

The Institute for the Study of Labor (IZA) in Bonn is a local and virtual international research center and a place of communication between science, politics and business. IZA is an independent nonprofit company supported by Deutsche Post World Net. The center is associated with the University of Bonn and offers a stimulating research environment through its research networks, research support, and visitors and doctoral programs. IZA engages in (i) original and internationally competitive research in all fields of labor economics, (ii) development of policy concepts, and (iii) dissemination of research results and concepts to the interested public.
\end{abstract}

IZA Discussion Papers often represent preliminary work and are circulated to encourage discussion. Citation of such a paper should account for its provisional character. A revised version may be available directly from the author. 
IZA Discussion Paper No. 2394

October 2006

\section{ABSTRACT}

\section{The Nonlinear Link between Height and Wages: An Empirical Investigation}

This article investigates the relationship between individual wages and height using the German Socio-Economic Panel where five hypotheses are tested. Some explanations of a positive link exist and empirical studies confirm this hypothesis. In contrast to previous investigations which are only based on a linear effect this paper finds that the individual height effects on wages are curvilinear. During the considered period from 1985 to 2004 we observe a slightly nonlinear falling trend. After controlling for time effects a nonlinear relationship between individual height and wages remains with a maximum below the average height for females and above the average for males. We detect endowment and discrimination influences. The latter are firstly due to employer discrimination and secondarily less likely due to customer discrimination.

JEL Classification: J15, J31

Keywords: height, wages, nonlinear, cyclical effects, discrimination

Corresponding author:

Olaf Hübler

Institute of Empirical Economic Research

Leibniz University of Hannover

Königsworther Platz 1

D-30167 Hannover

Germany

E-mail: huebler@ewifo.uni-hannover.de 


\section{Introduction}

Individual wages depend on factors such as schooling, experience and tenure which influence the productivity. Mincer's earnings function, which is one of the success stories in labour economics, considers these factors. Worldwide thousands of regressions of this type have been estimated over the last 50 years (Heckman/Lochner/Todd 2003). Nevertheless we have the feeling that this is not enough. On the one hand, goodness of fit measures are usually not higher than 0.5 and, on the other hand, anecdotal evidence demonstrates us that further personal and firms' characteristics are important for earnings. While gender and marital status are incorporated in many earnings functions, recently aspects of appearance are also discussed. In particular, friendship relations in the school class (Galeotti/Mueller 2005), beauty (Hamermesh/Biddle 1994, Biddle/Hamermesh 1998, Mobius/Rosenblat 2004), weight (Averett/Korenman 2001, Cawley 2004, Cawley/Danziger 2004), height (Persico/Postlewaite/Silverman 2004) and body mass index (Kennedy/Garcia 1994, Behrman/Rosenzweig 2001, Conley/Glauber 2005, D'Hombres/ Brunello 2005) were discovered as potential wage determinants. In the following we focus on body height. Many examples suggest that tall people are more successful than others. Of 43 American presidents, only five have been more than a smidgeon below average height. In the past 13 US presidential elections, the taller candidate has won 10 times. Presidents tend to be taller than the average population (Persico/Postlewaite/Silverman 2004). Gladwell (2005) reports the results of his survey on about one-half of the CEOs of Fortune 500 companies. He finds that the average CEO is approximately 3 inches taller than the average of the male American population. Are these isolated cases or are there systematic effects behind these observations? For most sports, height is useful as it affects the leverage between muscle volume and bones to allow greater speed of movement. Of course, basketball and volleyball players have advantages if they are tall, but why should we expect that in other fields, in other occupations employers pay a height wage premium? Examples such as horse riders, gymnasts or tank drivers exist where shortness is far more valuable.

The purpose of this paper is to test whether height is an economic category, whether in Germany taller workers earn more money than other employees or whether there exists a nonlinear relationship. In the next two sections the paper discusses some theoretical background and reports on empirical evidence from other studies. Then the data is described and descriptive results are presented. The main part is focussed on econometric results. The final section concludes.

\section{Theoretical Background}

Several plausible hypotheses exist why markets pay shorter people less. The main question as in the debate on gender wage differentials is whether the wage gap is based on unmeasured productivity factors or on discrimination. This means we have distinguish two possible explanations: 
(1) Tall people have characteristics which have positive effects on productivity but these factors are usually neglected in empirical studies.

(2) Short people are discriminated on the labour market due to cultural and social stigma.

Evolutionary theory and social psychology can explain the wage differences between short and tall workers. In former times the latter had direct advantages in the competition for resources. Nowadays, society still has yet preferences to communicate with tall people. Both, short and tall employees prefer tall colleagues. Discrimination of short people may be the consequence. Galbraith (1985) argues: One of the few forms of discrimination still prevalent today is that against small people whereas their taller peers are gifted extra sympathy. Self-fulfilling prophecies can strengthen this effect. Short children who believe that they have disadvantages in the future invest less in human capital because subjectively their returns are lower. Or they believe that they have to work harder in order to attain the same result as taller people. In many cases, this means that they do not keep cool, that they work doggedly. And then they have actual disadvantages.

Other theoretical strands stress that tall people indeed have a higher productivity. Historically, it is a fact that height increases in prosperous periods and that average height depends on the general standard of living. The better is the nutrition the better is the health status on the one hand, and the taller is the population. Komlos and Baur (2003) emphasize that height is a function of income inasmuch as the consumption of nutrients, particularly of proteins, vitamins, and minerals, and the regularity with which they are consumed, influence height at a particular age until adulthood. The average height of the population is an indicator of the biological prosperity and standard of living. If taller worker are healthier their productivity should exceed ceteris paribus that of short employees. Kriwy, Komlos and Baur (2003) take a step forward and consider the relationship between social status and height. Better educated and wealthier parents are better informed about a good nourishment of their children and they are also able to afford more expensive goods. Thus, we have to expect that the higher is the social position the taller descendants are on average. As better educated parents know that markets pay height premiums they will strengthen their efforts for their children.

A new idea is presented by Persico/Postlewaite/Silverman (2004). While prior research has believed that tall adults earn more money, the three authors emphasize: "What matters most is how tall a person was as a teenager." They explain the teen-height premium by a set of skills that is accumulated at earlier stages of development. If this characteristic is unobservable for the researcher, the lower wages of short employees are not due to the height but due to lack of human capital. Short teenagers who are stigmatized because of their status have problems to develop interpersonal skills, positive self-conception, or might simply excluded 
from participation in groups. They are less easygoing and more risk averse. Tall high-school kids learn to think of themselves as leaders, and that habit of thought persists even when they stop growing. They have learned to interact with people and this is important for a successful working life. The big point of this new approach is that height increases the chances that teens participate in social activities such as non-academic clubs and sports. This participation, in turn, helps them learn skills that are rewarded by employers and might enhance productivity.

A further connection between height and wages is induced by the inheritance of height. A tall father is likely to have also a tall son and a short mother will likely have a short daughter. The heights of parents and family are a fairly good predictor for the height of their children. Francis Galton (1865) has already analyzed the relationship between the body height of parents and children in his major work "Hereditary Genius, its Laws and Consequences". He found that there is positive correlation but there is also a regress to the mean. The term "regression" stems from this result. It seems interesting to investigate whether this outcome persists nowadays. This is not so obvious because we also observe another development, namely that the young generation is taller than the older generations. If the generation of tall parents was successful, because they had specific abilities, and we combine inheritance of height with inheritance of abilities, an additional argument is provided for the link between height and wages. Family resources such as intellectual stamina or work energy raise the children's productivity independent of external factors.

Height can also be interpreted as a specific characteristic of the appearance. In this context positive effects on wages through height are possible. Appearance can affect confidence and communication, thereby influencing productivity. For example private attorneys need to attract and keep clients. Tall men - as Nettle (2002) argues - have a greater ability to attract mates. Those who are considered unattractive or short, experience a significant earnings penalty. Moreover, lower marriage rates are found for those who are short or unattractive (Harper 2000). Especially, for men shortness is often a disadvantage with women finding short men less attractive and other men less likely to respect them. Sometimes the opposite is suggested for women where tallness may be seen as unattractive to some men. The hypothesis is that in this society, dominance is regarded as a trait which taller people possess. People choose mates who fit this social mode (Rubenstein/Wissman/Meyers 1998).

\section{Previous Empirical Studies}

Some studies focus on the determinants of height, while others investigate consequences of height growth. Komlos and Baur (2003) document that socio-economic and epidemiological environment primarily during childhood and adolescence is important for the individual physical stature. Social status is usually an important determinant of height. Better educated parents have superior consumption 
skills and they are better informed about long-range health effects of consumption patterns. The authors compare the average height of the American and European population during the last century. While in the 19th century Americans reach modern levels well above European standards for a long time, nowadays the former are considerably shorter than Western and Northern Europeans. Dutch, Swedish and Norwegian people are now the tallest. Americans are far from achieving the highest biological standard of living in the world today, in spite of their high average per capita income. Nevertheless, based on a sample from the publicuse data of the National Health and Nutrition Examination Survey III, collected between 1988 until 1994, the investigation finds a positive association between height and household income of the American population. Even the height of the American upper-income groups failed to keep up with that of the Western Europeans. Among blacks heights increased rapidly especially among upper income groups up to and including the World War II birth cohorts. The height average of college students was greater among whites than among blacks, but tended to stagnate. The gap between the lowest and highest educational group widened. Furthermore, high obesity rates are observed in all groups. This development can partially be explained by fast-food culture. Komlos and Baur stress four major differences between the socio-economic and political systems in Europe and the US:

- social inequality

- health care system

- welfare system

- spatial inequality.

Western European countries have advantages in these fields and this may be responsible for the higher biological standard of living.

Kriwy/Komlos/Baur (2003) and Komlos/Kriwy (2003) investigate the association between social status and height based on 7124 individuals from the German Federal Health Survey in 1998. An indicator, developed by Winkler (1998), measures social status. The study finds a strong relation. The higher the status the taller the people are on average. In addition, the results show height advantages of Western Germans compared with Eastern Germans. After the German reunification these differences vanish widely for males. The unification effect is not observed for females. The authors conclude that the Western German welfare state with a mixed economy was more conductive to the growth of the human organism than the state-socialist system in the East. Two facts are interesting to note. Firstly, the height differences between the Eastern and Western German population had already begun to reduce before the unification. Secondly, height differences induced by social status were also observed in the GDR. Children from better educated mothers were taller on average than those from less educated mothers.

Nutrition as a height's determinant is mentioned in several studies. For example, 
Baten $(1999,2000)$ describes this point in detail during the Bavarian development in the 19th century. Oerter and Dreher (1995, p. 331) also bring out the fact that wrong and lacking nutrition affect the growth of adolescents negatively. Investigations into determinants of height lead to the formulation of instrumental variables. Global and individual instruments can be used

- community residential conditions, such as supply of health-related services and infrastructure, as well as environmental conditions

- race and ethnic group

- educational attainment of the mother and father.

While the causality between nutrition and height seems unambiguous, the relation between health and height is not so clear. On the one hand, good health and health services bring forward the growth of children and adolescents. On the other hand, it is argued that tall people enjoy a better health, that they are more robust to illness and deprivation (Persico/Postlewaite/Silverman 2004, p. 1022). However, this point is controversially discussed in the literature. Samaras/Elrick (2002) and Samaras/Elrick/Storms (2003, 2004) see physical advantages of shorter height. Those people have shorter reaction time, greater ability to accelerate body movements and stronger muscles in proportion to body weight. They are less likely to break bones in falling or to die in car crashes. The papers illustrate a greater longevity of shorter people. Bigger bodies have more cells and these cells are subject to replacement due to wear or damage. Taller people have a 20 to $60 \%$ higher incidence of cancer compared to shorter people. The studies have also found that shorter people have substantially lower rates of coronary heart disease and very low cardiovascular disease rates.

In the literature, effects of height on wages are measured by foetal growth (Behrman/Rosenzweig 2001), height at ages 7, 11, 16 (Persico/Postlewaite/Silverman 2004), adult height (Heineck 2005) and instrumental variables associated with height (Schultz 2002). Errors in the measurement of height can lead to bias in OLS estimates. Therefore instruments related to height might be useful.

Behrman and Rosenzweig (2001) use data from the Minnesota Twin Registry, assembled between 1983 and 1990, to explore the relationship between physical characteristics and earnings. The sample is restricted to female twins. To investigate whether employers directly reward or punish height, log wage equations including height were estimated. The results are the following: Height has a statistically significant positive effect on the wage of females while no BMI effect can be detected. Foetal growth is strongly positively correlated with schooling, height and $\log$ wages. The findings do not indicate any support for policies increasing foetal growth on the grounds of intergenerational nutritional links between 
mothers and their children. However, the increased adult height reflects greater childhood nutritional intakes.

Heineck (2005) also analyzes whether taller employees earn more than shorter workers. Using GSOEP data from 1991 to 2002 for full and part-time, blue and white collar workers if they were aged 21-50 in 2002 the study finds a height premium for males from Western Germany of more than $4 \%$ for additional 10 $\mathrm{cm}$ in height. No significant effects could be detected for females and males from East Germany.

The most extensive study on height and wages is presented by Persico/Postlewaite and Silverman (2004). Data are used from Britain's National Child Development Survey (NCDS) and from the National Longitudinal Survey of Youth (NLSY). The former survey began as a perinatal study of all children born in England, Scotland and Wales during the week beginning March 3, 1958. The children were interviewed again when they were $7,11,16,23$ and 33 years old. $66 \%$ of the original sample with 17,414 children could be recontacted at age 33 . The height is available age $7,11,1633$. The NLSY began in 1979 with 12,686 people aged 14-21 and has interviewed this cohort every year until 1994. Height was collected in 1981 and 1985. The authors focus their investigation on white males. The main outcome is that in both data sets the teen height, but not the adult height is positively significantly correlated with log wages when controlling for variables such as education, work experience, race, gender, region, industry, occupation, family and school background. Tall men who were short in high school earn like short men, while short men who were tall in high school earn like tall men. Although the estimated coefficients on height are somewhat reduced after accounting for differences in some external resources, the reduction is minor. Additional investigations demonstrate that the premium of height in adolescence is not due to outliers, linear specification, adult or pre-teen height. Employers taste for height does not seem to be important. Discrimination is ruled out as an explanation. Observable and unobservable resources are also excluded as a reason. Thus, it follows that height cannot be interpreted as proxies for good health, for weight, for native intelligence or early cognitive development. The authors believe that tall high-school kids learn to think of themselves as leaders. Self-confident once learned lasts a lifetime. A self-confident teenager is more likely to join teams, clubs, and social groups where he learns to interact with people and this is an important characteristic in the working life. Those who are short when young are less likely to participate in social activities.

Psychological studies also emphasize that the physical appearance during adolescence influences the range of interaction with others and that this ability is effective over the entire life (Silbereisen/Schmidt-Rodermund 1999, p. 232). Tall boys mature earlier, behave as adults earlier and will more likely become leader in their peer group. This means, they are more responsible, cooperative and 
self-confident (Oerter/Dreher 1995, p. 337). Kuhn and Weinberger (2005) emphasize high school leadership which is connected with drive, energy, work ethic, persistence and motivation - characteristics which are useful labour market characteristics. Persons with these skills will be assigned to occupations such as managerial ones. Kuhn and Weinberger's study is based on three data sets (Talent Study of High School Students, NLS72 and High School and Beyond). The authors exclude that the leadership variable is acting as a proxy for unobserved determinants of earnings such as beauty or physical attractiveness. Adding height to the wage regressions with leadership as an explanatory variable the latter effect is almost identical to that without height and the height coefficient is generally insignificant.

\section{Data, Hypotheses and Descriptive Results}

The empirical analysis is based on representative micro-data from the German Socio-Economic Panel (GSOEP) which has been collected since 1984. I use data collected from 1985 to 2004. Employees aged 25 to 55 following Schultz (2002) and working full or part-time are only considered. For technical details of the GSOEP see Haisken-DeNew and Frick (2003). The panel started in 1984 with 5,921 households and 12,290 individuals. In 1991 the sample was supplemented by data from Eastern Germany. In this year information from 6,699 households and 13,669 individuals were available. In 2004 the sample contains 11,796 households and 22,019 individuals. It contains a wide range of socioeconomic and labour market variables. Body height and weight were only asked in 2002 and 2004. As we can assume that height is usually time invariant for people 25 years and older, it is possible to link the height information to prior and later waves for the age group 25 to 55 . Nevertheless, the height information varies in many cases between 2002 and 2004. In the following I use the average from the two years. The mean difference of height between 2002 and 2004 is $\bar{x}=0.0146 \mathrm{~cm}\left(s_{x}=2.2214 \mathrm{~cm}\right)$.

The following empirical investigation tests five hypotheses:

(1) Tall employees earn on average more than other workers.

(2) The incorporation of additional (a) observed and (b) unobserved earnings determinants reduce but do not eliminate the height wage premium.

(3) A nonlinear trend and cyclical effects exist for the height wage premium.

(4) Individual height effects on wages are nonlinear.

(5) The height effect on wages expresses a preference for tall people and differs for males and females, but the height wage premiums is not only due to discrimination by customers or employers. Endowment and productivity effects also exist. 
At first, some descriptive results - see Table 1 and 2 - are presented, before the econometric analysis is started. The average height in Germany within the period 1985-2004 is $172.88 \mathrm{~cm}$. Table 1 demonstrates that height varies substantially between several characteristics. T-tests on the equality of means show that height between males and females differs significantly. Moreover, younger employees are taller than older employees. It is interesting to note that managers are taller than non-managers and employees with working overtime are also taller than those without working overtime. Some other characteristics such as job change, public sector, absenteeism and satisfaction with health do not seem vary with height $(\alpha>0.01)$. This is not always compatible with theoretical expectations. Multivariate analyses have to show whether these univariate results are robust.

Table 1: Tests on equality of height means between individual dichotomous characteristics $(\mathrm{D}=0 ; 1)$

\begin{tabular}{|l||cc|c||c||c||}
\hline & $\begin{array}{c}\text { all } \\
\bar{x}(\mathrm{D}=0)\end{array}$ & $\bar{x}(\mathrm{D}=1)$ & $\mathrm{T}$ & $\begin{array}{c}\text { males } \\
\mathrm{T}\end{array}$ & $\begin{array}{c}\text { females } \\
\mathrm{T}\end{array}$ \\
\hline males (=1) & 165.80 & 178.24 & $-310^{* *}$ & & \\
\hline $\begin{array}{l}<25 \text { years } \\
(=1)\end{array}$ & 172.63 & 174.07 & -17.39 & $-19.19^{* *}$ & $-22.40^{* *}$ \\
\hline $\begin{array}{l}\text { >55 years } \\
(=1)\end{array}$ & 172.89 & 171.50 & $13.11^{* *}$ & $19.94^{* *}$ & $14.11^{* *}$ \\
\hline $\begin{array}{l}\text { computeruse } \\
\text { yes (=1) }\end{array}$ & 172.20 & 173.58 & $-19.80^{* *}$ & $-30.83^{* *}$ & $-17.52^{* *}$ \\
\hline $\begin{array}{l}\text { profit sharing } \\
\text { yes (=1) }\end{array}$ & 172.45 & 175.91 & $-32.11^{* *}$ & $-19.09^{* *}$ & $-5.35^{* *}$ \\
\hline $\begin{array}{l}\text { quit } \\
\text { yes (=1) }\end{array}$ & 172.81 & 173.16 & $-2.42^{*}$ & $-5.95^{* *}$ & $-5.12^{* *}$ \\
\hline $\begin{array}{l}\text { layoff } \\
\text { yes (=1) }\end{array}$ & 172.82 & 172.86 & -0.22 & $3.17^{* *}$ & 0.41 \\
\hline $\begin{array}{l}\text { overtime } \\
\text { yes (=1) }\end{array}$ & 171.46 & 173.83 & $-44.56^{* *}$ & $-19.41^{* *}$ & $-13.36^{* *}$ \\
\hline $\begin{array}{l}\text { public sector } \\
\text { yes (=1) }\end{array}$ & 173.30 & 171.71 & $27.74^{* *}$ & $-8.66^{* *}$ & 1.07 \\
\hline $\begin{array}{l}\text { region } \text { east } \\
\text { yes (=1) }\end{array}$ & 172.26 & 173.69 & $-26.06^{* *}$ & $-20.33^{* *}$ & $-22.28^{* *}$ \\
\hline $\begin{array}{l}\text { schooling parents } \\
\text { low(=1) }\end{array}$ & 173.06 & 168.13 & $41.93^{* *}$ & $55.55^{* *}$ & $33.69^{* *}$ \\
\hline $\begin{array}{l}\text { union member } \\
\text { yes (=1) }\end{array}$ & 172.68 & 173.52 & $-7.10^{* *}$ & $8.11^{* *}$ & $5.60^{* *}$ \\
\hline $\begin{array}{l}\text { property } \\
\text { yes (=1) }\end{array}$ & 172.46 & 173.19 & $-13.70^{* *}$ & $-9.09^{* *}$ & $-5.68^{* *}$ \\
\hline $\begin{array}{l}\text { manager } \\
\text { yes (=1) }\end{array}$ & 172.20 & 176.14 & $-53.58^{* *}$ & $-23.94^{* *}$ & $-12.53^{* *}$ \\
\hline $\begin{array}{l}\text { absenteeism } \\
\text { yes (=1) }\end{array}$ & 175.70 & 172.80 & 1.00 & 1.48 & 1.81 \\
\hline $\begin{array}{l}\text { health } \\
\text { bad (=1) }\end{array}$ & 172.81 & 171.32 & $5.17^{* *}$ & $2.71^{* *}$ & $3.35^{* *}$ \\
\hline $\begin{array}{l}\text { health-satis- } \\
\text { saction low (=1) }\end{array}$ & 172.82 & 171.91 & $5.20^{* *}$ & $1.98^{* *}$ & $2.36^{*}$ \\
\hline
\end{tabular}

Source: GSOEP $1985-2004 ; * *=$ significant at $\alpha=0.01 ; *=$ significant at $\alpha=0.05$ 
The correlation of $\mathrm{r}=+0.278$ between height and wages gives some preliminary evidence for hypothesis (1). However, if we separate by gender and age groups or between Eastern and Western Germany the relationship is less strong. For example, within the group of male employees a correlation coefficient of $r=+0.1$ only results. We find a stronger dependency in the West than in Eastern Germany (e.g. for middle aged male workers in the private sector $(r$ west $)=0.173$ vs. $\mathrm{r}($ east $)=0.115)$.

Table 2: Descriptive statistics of the gross wage per hour (w), split by gender $($ male $=1 ; 0)$ and height $(h)$ groups in $\mathrm{cm}$

\begin{tabular}{|l|cc|}
\hline & mean & std. dev \\
\hline male $=1 ; \mathrm{h}>=185$ & 13.24 & 6.52 \\
male $=1 ; 171<\mathrm{h}<185$ & 15.27 & 7.73 \\
male $=1 ; \mathrm{h}<=171$ & 13.81 & 6.54 \\
\hline male $=0 ; \mathrm{h}>=172$ & 10.44 & 5.14 \\
male $=0 ; 159<\mathrm{h}<172$ & 12.44 & 5.73 \\
male $=0 ; \mathrm{h}<=159$ & 11.28 & 5.18 \\
\hline
\end{tabular}

Source: GSOEP 1985-2004

Table 2 presents some descriptive results on the monthly gross wage split for gender and height groups. The height is subdivided into groups within and outside the interval of one standard deviation of the mean $\left(\bar{x}-s_{x} ; \bar{x}+s_{x}\right)$ for males and females. Here we observe the interesting fact that wages are largest within the central interval. This result is at odds with hypothesis (1). As a consequence of the descriptive outcome I control for other wage determinants and I analyse nonlinear relations.

\section{Methods and Econometric Outcomes}

\subsection{Height Wage Premium in Pooled and Panel Estimates}

The investigation starts with an OLS estimation of wage functions using pooled data from 1985 to 2004 including height as an explanatory variable. All the estimates with different combinations of control variables find a positively significant height wage premium - see Table 3, column (1)-(3). This is in accordance with hypothesis (2a). For example, from the estimates in column (3) we see that $2.8 \%$ higher wages result if a person is $10 \mathrm{~cm}$ taller. All control variables have the expected effect on wages. Nevertheless, the return rate and the t ratios are decreasing if additional earnings determinants are considered. 
Table 3: OLS estimates of log wages per hour with height as a determinant

\begin{tabular}{|c|c|c|c|c|c|c|}
\hline $\operatorname{lnWAGES}$ & $\begin{array}{c}(1) \\
\text { Coef. }\end{array}$ & Std. Err. & $\begin{array}{c}(2) \\
\text { Coef. }\end{array}$ & Std. Err. & $\begin{array}{c}(3) \\
\text { Coef. }\end{array}$ & Std. Err. \\
\hline HEIGHT & $0.01191 * *$ & 0.00025 & $0.00541 * *$ & 0.00029 & $0.00280 * *$ & 0.00026 \\
\hline SCHOOLING & & & $0.07094 * *$ & 0.00071 & $0.04249^{* *}$ & 0.00081 \\
\hline TENURE & & & $0.02321 * *$ & 0.00070 & $0.01771^{* *}$ & 0.00071 \\
\hline TENURE $^{2}$ & & & $-0.00035^{* *}$ & 0.00002 & $-0.00025 * *$ & 0.00002 \\
\hline EXPERIENCE & & & $0.00100^{* *}$ & 0.00011 & $0.00072^{* *}$ & 0.00011 \\
\hline EXPERIENCE $^{2}$ & & & $3.0 \mathrm{e}-06 * *$ & $5.16 \mathrm{e}-07$ & $1.07 \mathrm{e}-06^{* *}$ & $4.70 \mathrm{e}-07$ \\
\hline MALE & & & $0.11226^{* *}$ & 0.00535 & $0.07560^{* *}$ & 0.00526 \\
\hline NEW LAENDER & & & & & $-0.23257 * *$ & 0.00422 \\
\hline FIRM SIZE & & & & & $0.04406^{* *}$ & 0.00182 \\
\hline N OF JOB CHANGES & & & & & $0.00568 * *$ & 0.00157 \\
\hline MANAGER & & & & & $0.23617^{* *}$ & 0.00478 \\
\hline PROFIT SHARING & & & & & $0.14064 * *$ & 0.00570 \\
\hline SCHOOLING PARENTS & & & & & $0.02291 * *$ & 0.00054 \\
\hline 62 INDUSTRIES & - & & - & & + & \\
\hline CONSTANT & 0.47968 & 0.04384 & $0.38829 * *$ & 0.04761 & $1.26306^{* *}$ & 0.06375 \\
\hline $\mathrm{N}$ & 37529 & & 36754 & & 34181 & \\
\hline $\mathrm{R}^{2}$ & 0.0562 & & 0.3442 & & 0.5132 & \\
\hline
\end{tabular}

The next step is to test hypothesis (2b) whether the height effect is an artefact due to unobserved earnings determinants. For this purpose a panel estimator is applied. Here we have the problem that Hausman tests usually reject the random effects model (REM), while the fixed effects model (FEM) has the problem that the within transformation of a model wipes out time invariant regressors as well as the individual effect. Thus, it is not possible to estimate the effects of those regressors on the dependent variable. One way to solve this problem is the Hausman-Taylor estimator (Hausman/Taylor 1981). The major limitation of this estimator is that it requires specifications of which regressors are either correlated or not correlated with the individual effects (Cameron/Trivedi 2005, p. 761). A priori it is difficult to decide which regressors are correlated with the unobserved individual effects. Furthermore, the estimator reacts very sensible to the specification. Amemiya and MaCurdy (1986) present a more efficient estimator. However this approach requires a balanced panel and the sensitivity problem also exists. Therefore, we suggest an alternative (Hübler 2003, 2006). The basic idea follows the sample selection approach. Heckman (1979) has substituted the conditional expected error term by an estimate, which is employed as an artificial regressor. We estimate the individual effects and incorporate these estimates in the earnings function. The following model with individual effects is used

$$
\ln w_{i t}=h_{i} \gamma+x_{i t}^{\prime} \beta+\alpha_{i}+u_{i t}
$$

where $\ln w$ are $(\log )$ wages per hour, $h_{i}$ is the height of individual i, $x_{i t}$ is the vector of other earnings determinants of $\mathrm{i}$ in period $\mathrm{t}, \alpha_{i}$ is the unobserved effect of i, $\beta$ and $\gamma$ are coefficients and $u_{i t}$ is the error term. In the first step the general individual effects $\alpha_{i}$ are estimated by the within estimator of a fixed effects model

$$
\hat{\alpha}_{i}=\left(\bar{y}_{i}-\bar{y}\right)-\left(\bar{x}_{i} *-\bar{x} *\right)^{\prime} \hat{\beta} *
$$


where $\beta^{*}$ is the coefficient vector without the constant term. The conventional random effects estimator is inadequate if individual effects and regressors are correlated. This raw individual effect $\hat{\alpha}_{i}$ in (2) does not only measure the individual effects but also contains effects from time-invariant determinants $\mathrm{z}$ where $\mathrm{z}$ is defined by determinants from Table $3: \mathrm{z}=\mathrm{z}$ (HEIGHT, MALE, NEW LAENDER, SCHOOLING PARENTS, ind1, ..., ind62, y1985, ..., y2004). Therefore, we have to adjust $\hat{\alpha}_{i}$ by OLS estimates of

$$
\hat{\alpha}_{i}=z_{i}^{\prime} \delta+\epsilon_{i}
$$

namely we have to calculate $\hat{\alpha}_{i}-z_{i}^{\prime} \hat{\delta}=\alpha_{a d j ; i}$. At the second step the individual effects are substituted by the estimates of the first step. We incorporate $\alpha_{a d j}$ as artificial regressor. The following model

$$
\ln w_{i t}=h_{i} \gamma+x_{i t}^{\prime} \beta+\kappa \alpha_{a d j ; i}+u_{i t}
$$

incorporates explicitly the individual effects and therefore we can use a pooled estimator in the second step. We have to expect that the estimates of $\kappa$ are (near) one. In contrast to the fixed effects estimator the pooled OLS estimates can also determine time-invariant effects such as height effects. As the regressor $\alpha_{a d j ; i}$ $\left(A L P H A_{i}\right)$ is estimated we do not use conventional standard errors but bootstrap standard errors. Table 4 presents pooled estimates in column (1). The height effect in this specification does not differ substantially from those in specification (3), Table 3. The coefficient is statistically significant positive and a little bit smaller than before. So we can argue that the unobserved individual effects which are significant do not strongly affect the wage premium of height.

A further problem is the variability of height in 2002 and 2004. For the age group 25 to 55 we expect a constant height. Variations are due to measurement errors. This can be tested (Hübler 1989, p. 240, Cameron/Trivedi 2005, p. 908, 276). For this purpose we estimate

$$
\ln w_{i t}=h_{i} \gamma+x_{i t}^{\prime} \beta+\hat{\omega}_{i t} \tilde{\beta}+\kappa \alpha_{a d j ; i}+u_{i t}
$$

where $\hat{\omega}_{i t}$ is the estimated measurement error of $h_{i}$ in period t $\left(h_{i t}=h_{i}+\omega_{i t}\right)$. We assume the difference of observed height in 2002 and $2004\left(\Delta h=h_{2002}-h_{2004}\right)$ as an indicator of $\omega$. Therefore

$$
\Delta h_{i}=w_{i t}^{\prime} \xi+\zeta_{i t}
$$

is estimated where $w=w(M A L E, A G E, N E W L A E N D E R, M A N A G E R)$. These are statistically significant determinants. The results demonstrate - not reported in the Tables - that males, younger persons, non-manager and Eastern Germans have a lower propensity to misreport the height. The next step is to incorporate $\hat{\omega}=\widehat{\Delta h}=w^{\prime} \hat{\xi}$ in the earnings function (5) and to test $H_{0}: \tilde{\beta}=0$. 
As $H_{0}$ is rejected $\left(\hat{\tilde{\beta}}=-0.185\left(t_{\hat{\tilde{\beta}}}=-4.38\right)\right)$ we have to conclude the presence of measurement errors. As a consequence we use an IV estimator where height is substituted by two IVs

(7) $h_{I V, 1}=\hat{c}_{0}+\hat{c}_{1} \cdot$ health $_{\text {score }}+\hat{c}_{2} \cdot$ school $_{\text {mother }}+\hat{c}_{3} \cdot$ school $_{\text {father }}+\hat{c}_{4} \cdot$ region $_{N W}$

or

(8) $h_{I V, 2}=\hat{c}_{0}+\hat{c}_{1} \cdot$ health $h_{\text {score }}$.

In a sense I follow Schultz (2002) who has used four sets of instruments where the third combines the first two: health-related indicators and education of the mother and father. For this purpose the variables health score $(=1$, if the health status is very good; ...; $=5$, if the health status is bad), school mother $_{\text {and }}$ school $_{\text {father }}$ (measured in number of years) are employed. As a final set of instruments Schultz uses ethnic and language groups. In preliminary investigations I have applied a dummy foreign $(=1$, if the person is a foreigner) and regional dummies. Komlos and Kriwy (2003) have found height disadvantages of Eastern Germans. One reason are differences in the ethnic origin. If we compare the average height with that in some other regions we detect that Southern Germans are also smaller than Northern and Western Germans. Therefore, the dummy $\operatorname{region}_{N W}(=1$, if the person lives in Northern or Western Germany) is constructed. This indicator is better than the dummy NEWLAENDER, because the latter is strongly correlated with wages. This argument speaks also against school $_{\text {mother }}$ and school $_{\text {father }}$. These variables are positively correlated with wages. Only health $h_{\text {score }}$ is empirically completely uncorrelated with wages. This is the major reason that besides $h_{I V ; 1}$ in (7) also $h_{I V ; 2}$ in (8) is applied.

If we augment the earnings function by $h_{I V, 1}$ or $h_{I V, 2}$, respectively, instead of directly measured HEIGHT, estimates (2)-(3) follow in Table 4. We should note that Schultz' investigations with height instruments lead to larger impact than OLS association between height and wages. In our IV estimates the height effect is not significant or we observe a dramatic increase if time dummies are considered which are highly significant. Several explanations are possible. Firstly, the height effects on wages are an artefact. We observe a positive development of height and wages but causal relationship may not exist. On the one hand, over the last 30 years we observe a rising average height due to better health service and nourishment. On the other hand, wages grow by increasing productivity. If time dummies are neglected this effect is incorporated in the height influence. Secondly, besides a trend underlying height and wages cyclical movements are effective (hypothesis 3). Multicollinearity between time dummies and height may lead to insignificant height effects. Thirdly, there does not exist a linear, but a nonlinear relation between height and wages (hypothesis 4). 
Table 4: Panel estimates of log wages per hour with height as a determinant

\begin{tabular}{|c|c|c|c|c|c|c|}
\hline \multirow[b]{2}{*}{$\ln w$} & \multicolumn{2}{|l|}{ (1) } & $(2)$ & \multicolumn{3}{|c|}{ (3) } \\
\hline & Coef. & $\begin{array}{l}\text { Bootstrap } \\
\text { Std. Err. }\end{array}$ & Coef. & $\begin{array}{l}\text { Bootstrap } \\
\text { Std. Err. }\end{array}$ & & $\begin{array}{l}\text { Bootstrap } \\
\text { Std. Err. }\end{array}$ \\
\hline HEIGHT & $0.00269 * *$ & 0.000127 & & & & \\
\hline$h_{I V, 1}$ & & & 0.00152 & 0.001383 & & \\
\hline$h_{I V, 2}$ & & & & & $0.00882^{* *}$ & 0.004156 \\
\hline SCHOOLING & $0.01440 * *$ & 0.000420 & $0.01557 * *$ & 0.000462 & $0.01552^{* *}$ & 0.000519 \\
\hline TENURE & $0.00770 * *$ & 0.000355 & $0.00752^{* *}$ & 0.000360 & $0.00750^{* *}$ & 0.000399 \\
\hline TENURE $^{2}$ & $-0.00021^{* *}$ & 0.000011 & $-0.00021^{* *}$ & $9.74 \mathrm{e}-06$ & $-0.00021^{* *}$ & 0.000011 \\
\hline EXPERIENCE & $0.00422 * *$ & 0.000057 & $0.00417 * *$ & 0.000076 & $0.00416^{* *}$ & 0.000067 \\
\hline EXPERIENCE $^{2}$ & $-7.26 \mathrm{e}-06^{* *}$ & $2.42 \mathrm{e}-07$ & $-7.05 \mathrm{e}-6^{* *}$ & $3.04 \mathrm{e}-07$ & $-7.02 \mathrm{e}-06^{* *}$ & $3.01 \mathrm{e}-07$ \\
\hline MALE & $0.04880^{* *}$ & 0.002515 & $0.08339 * *$ & 0.002260 & $0.08315^{* *}$ & 0.001866 \\
\hline NEW LAENDER & $-0.24556^{* *}$ & 0.002116 & $-0.24520^{* *}$ & 0.002394 & $-0.24629^{* *}$ & 0.002262 \\
\hline FIRM SIZE & $0.01928 * *$ & 0.000903 & $0.02108 * *$ & 0.001066 & $0.02105^{* *}$ & 0.001089 \\
\hline N OF JOB CHANGES & $0.01963 * *$ & 0.000780 & $0.01971 * *$ & 0.001029 & $0.02000^{* *}$ & 0.000951 \\
\hline MANAGER & $0.36040^{* *}$ & 0.002346 & $0.36027^{* *}$ & 0.002731 & $0.36025^{* *}$ & 0.002514 \\
\hline PROFIT SHARING & $0.14219 * *$ & 0.002811 & $0.15039 * *$ & 0.003195 & $0.15021 * *$ & 0.003178 \\
\hline SCHOOLING PARENTS & $0.02284 * *$ & 0.000679 & $0.02258^{* *}$ & 0.000935 & $0.02334^{* *}$ & 0.000744 \\
\hline $\mathrm{ALPHA}_{i}$ & $1 * *$ & 0.003463 & $1.00327^{* *}$ & 0.004535 & $1.00289 * *$ & 0.004244 \\
\hline 62 INDUSTRIES & + & & + & & + & \\
\hline 18 TIME DUMMIES & + & & + & & + & \\
\hline CONSTANT & 1.38468 & 0.031053 & $1.56203^{* *}$ & 0.235215 & $0.47021 * *$ & 0.673380 \\
\hline $\mathrm{N}$ & 32380 & & 25694 & & 26959 & \\
\hline $\mathrm{R}^{2}$ & 0.8880 & & 0.8881 & & 0.8887 & \\
\hline
\end{tabular}

Source: GSOEP 1985-2004, own calculations

In the following we test the third and the fourth hypothesis. For the former case, earnings functions with height as a regressor are determined separately for each wave from 1985 to 2004 in the first step. Then the estimated height coefficients are regressed on a trend $(\mathrm{T})$ and the lagged growth rate of the GDP $(\widehat{G D P}-1)$ as a cyclical determinant in the second step. The first step is based on the third specification in Table 3 . The outcome of the second step does not show significant effects. However, if a nonlinear trend is modelled we obtain ( $\mathrm{t}$ statistics in parentheses)

$$
\hat{\beta}_{\text {height }}=0.0104+0.00053 \cdot \widehat{G D P}-1-0.0007552 \cdot \mathrm{T}+0.0000346 \cdot T^{2}
$$

$R^{2}=0.369 \quad \mathrm{~N}=21$.

This means that we have a falling nonlinear height effect on wages during the observed period. The decreasing effect might be an artefact. Assuming, the average height is rising with a constant growth rate $\mathrm{c}>0$ from period $\mathrm{t}-1$ to period $\mathrm{t}$, then the absolute height effect is falling, if the rank of height and not the absolute height is relevant for the wage effect.

The other result from the above equation is the following: during a recession with low growth rate (in the last period) the height effect is weaker than during a boom with high growth rates. This is evidence that in hard economic periods the 
wage premium of tall compared to short people is decreasing. Apparently, the former have unobserved characteristics which are less important in a recession than in the boom. In section 2 we have mentioned that tall kids are more likely to become peer group leaders as well as being more easygoing while short kids learn to work hard. Our result speaks in favour of an increasing demand for the latter characteristics in a period of general downturn. Then short people are promoted into risky, difficult jobs where the chances of failure are higher. Michelle Ryan and Alex Haslam (2005) argue in a similar direction in their comparison between males and females. In an empirical study of the performance of 100 FTSE companies they find that women are more likely to be placed in precarious leadership positions. The company hopes that women on the board of directors decide more cautiously and enter less risky ventures.

The fourth hypothesis is tested by the LOWESS approach (Cleveland 1979, Cameron/Trivedi 2005, p.320), a nonparametric procedure, implemented separately for males and females. First, the height variable $(h))$ is adjusted by the regressors $\mathrm{x}$ of Table 4 where height is excluded $\left(h=x^{\prime} \gamma+\epsilon\right)$

(9) BODYHEIGHT_adj $=h-x^{\prime} \hat{\gamma}+\hat{\gamma}_{C O N S T A N T}$.

Second, the LOWESS procedure is applied to lnw as a dependent and BODY HEIGHT_adj as an independent variable. In Figure 1a and 1b the estimates are presented.

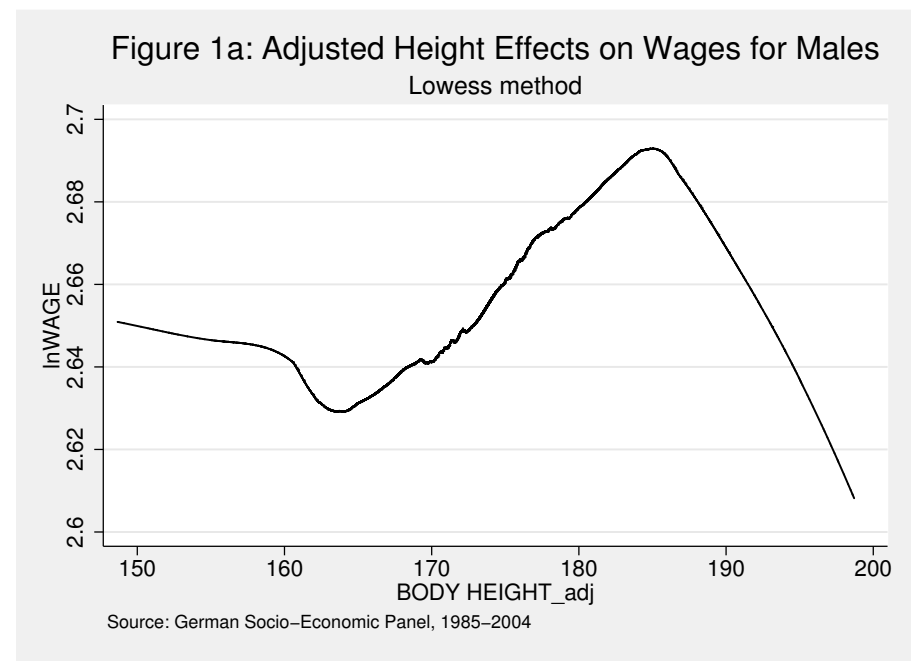

The graphs demonstrate that the relationship between (log) wages per hour and height is highly nonlinear which cannot be described by a simple specific function. A log-linear function seems to be an acceptable approximation - see Table 5 . 
Table 5: Panel estimates of log wages per hour with two specific nonlinear height functions

\begin{tabular}{|l||cccc||cccc||}
\hline & $(1 \mathrm{a})$ & & \multicolumn{1}{c||}{$(2 \mathrm{a})$} & & $(1 \mathrm{~b})$ & & $(2 \mathrm{~b})$ & \\
& Males & & & & Females & & & \\
lnw & Coef. & $\mathrm{t}$ & Coef. & $\mathrm{t}$ & Coef. & $\mathrm{t}$ & Coef. & $\mathrm{t}$ \\
\hline height $/ 10^{2}$ & -0.0027 & -0.52 & & & -2.9803 & -0.28 & & \\
height $^{2} / 10^{4}$ & 0.0001 & 0.48 & & & 0.0255 & 0.28 & & \\
height $^{3} / 10^{6}$ & -0.0813 & -0.44 & & & -0.0554 & -0.28 & & \\
height $^{4} / 10^{8}$ & 1.0900 & 0.40 & & & -6.600 & -0.28 & & \\
$\log ($ height $)$ & & & 0.4687 & 16.74 & & & 0.4505 & 12.05 \\
\hline $\mathrm{N}$ & 20210 & & 20210 & & 12170 & & 12170 & \\
$\mathrm{R}^{2}$ & 0.8831 & & 0.8831 & & 0.8734 & & 0.8734 & \\
\hline
\end{tabular}

Hint: Control variables are the same as in Table 4. Other nonlinear height function are tested (e.g. quadratic and cubic) but all others except the log linear height specification are insignificant.

The graphs - Figure $1 \mathrm{a}$ and $1 \mathrm{~b}$ - show that the usual statement of a linear relationship has to be rejected. Males reach the maximal height effect nearly $6 \mathrm{~cm}$ above the average male height. This is near the border of the twofold error interval. In the lower tail the relationship seems uncertain but males larger than 163 $\mathrm{cm}$ have positive increasing height effects on $(\log )$ wages until to the maximum. Then we find a negative link. The graph for females differs. Here, the maximum is observed a bit below the average female height. This is in favour of the hypothesis that preferences for means exist or in other words, especially female employees with a height far away from the average are discriminated against those females with an average height or that they have negative unobserved productivity characteristics. This is in accord with the descriptive result of Table 2.

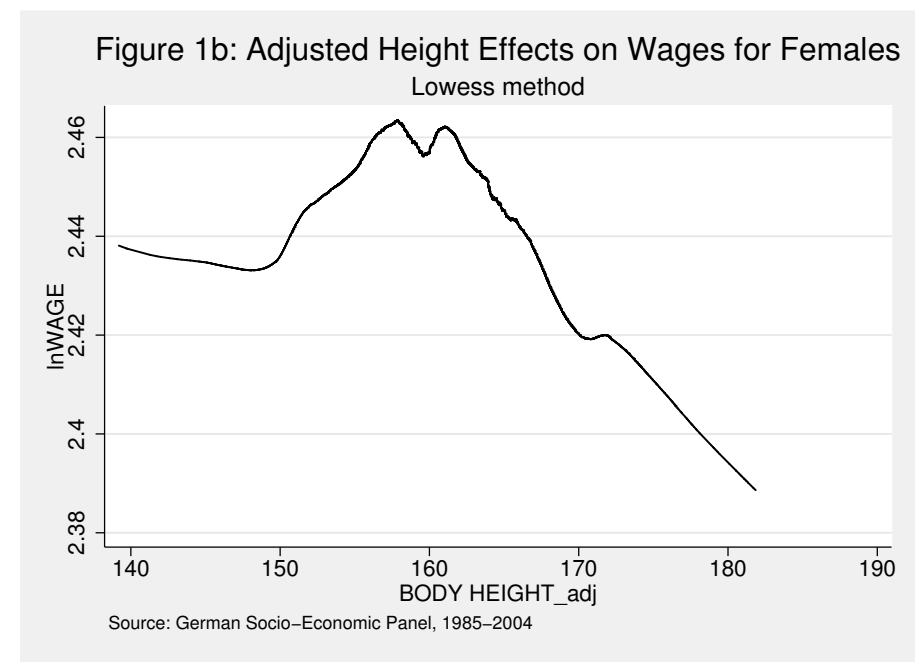




\subsection{Endowment, Productivity and Discrimination Effects}

In the next step I test hypothesis (5). For this purpose the wage differences between tall and short employees are decomposed. Tall workers are defined as those who have a body height larger than the average height (males $>178.24$; females $>$ 165.83 - see Table 1). We follow Blinder's (1973) procedure to decompose between endowment and unexplained effects. The latter may be due to discrimination or productivity differences. Table 6 presents the results where the specification of Table 4 without height is used. Discrimination against short male workers or productivity differences seems to be effective but it is less important than among females. A relevant part of the wage differences between tall and short people is explained by differences in the endowment. In detail - not presented in the Tables -, tall workers have a better education. The same is observed for their parents. Furthermore, less tenure and experience, work in larger firms and longer working times are typically observed. Tall and short people are not randomly allocated among the industries. And finally, we have detected a higher probability of the tall employees to participate in profit sharing and to work in a managerial position. These results are similar for males and females.

Table 6: Blinder Decomposition (as \%)

\begin{tabular}{|l|cc|}
\hline & $(1)$ & $(2)$ \\
& Males & Females \\
\hline Amount attributable: & 12.5 & 8.9 \\
- due to endowments (E): & 8.0 & 2.2 \\
- due to coefficients (C): & 4.5 & 6.7 \\
Shift coefficient (U): & -1.4 & -4.0 \\
Raw differential (R) E+C+U: & 11.1 & 4.9 \\
Adjusted differential (D) C+U: & 3.1 & 2.7 \\
\hline Endowments as \% total (E/R): & 71.8 & 44.7 \\
Discrimination as \% total (D/R): & 28.2 & 55.3 \\
\hline
\end{tabular}

$\mathrm{U}=$ unexplained portion of differential (difference between model constants), $\mathrm{D}=$ portion due to discrimination $(\mathrm{C}+\mathrm{U})$, positive number indicates advantage to high group, negative number indicates advantage to low group

The procedure developed by Juhn, Murphy and Pierce (1993) confirms Blinder's decomposition. Here we have three components, the contribution of differences in observable quantities (Q), observable prices (P) and in unobservable quantities and prices $(\mathrm{U})$. Again we are using the specification from Table 4 without height for the Juhn-Murphy-Pierce decomposition. Table 7 split those into males and females. 
Table 7: Juhn-Murphy-Pierce Decomposition

\begin{tabular}{|l|ccc|ccc|}
\hline & absolute & & & as \% & & \\
& $\mathrm{Q}$ & $\mathrm{P}$ & $\mathrm{U}$ & $\mathrm{Q}$ & $\mathrm{P}$ & $\mathrm{U}$ \\
\hline Males & 0.07937 & 0.03118 & 0.00016 & 71.7 & 28.2 & 0.1 \\
Females & 0.02158 & 0.02707 & 0.00028 & 44.1 & 55.3 & 0.6 \\
\hline
\end{tabular}

If discrimination exists - and the results in Table 6 and 7 give some evidence for this hypothesis - employers and customers may be responsible. Biddle and Hamermesh (1998) test this in the context of beauty by separate estimates for self-employed and dependent employees on the one hand and between private and public sectors on the other hand. This procedure can also be applied to height discrimination. If height effects appear for dependent employees but not among the self-employed, this is evidence in favour of employer's discrimination. Evidence for customer discrimination is a stronger height effect in the private sector than in the public sector. We find significant height effects for dependent employed workers while the analogous effect for self-employed is insignificant. Again specification from Table 4 is used. Separate estimates for the private and public sector lead to results in the right hand panel of Table 8.

Table 8: Earnings function split into dependent and self-employed workers, private and public sector with height effect

\begin{tabular}{|l|cc|cc|}
\hline & $\begin{array}{c}\text { dependent employed } \\
\text { workers }\end{array}$ & $\begin{array}{c}\text { self-employed } \\
\text { workers }\end{array}$ & private sector & public sector \\
\hline height & $0.0189(3.26)$ & $0.2497(0.90)$ & $0.0028(18.60)$ & $0.0024(10.28)$ \\
\hline $\mathrm{N}$ & 26954 & 170 & 22725 & 9610 \\
$\mathrm{R}^{2}$ & 0.8241 & 0.4470 & 0.8965 & 0.8633 \\
\hline
\end{tabular}

Hint: Control variables are the same as in Table 4

These estimates support the hypothesis of employer and customer discrimination against short people. We could also conclude that height is connected with productivity effects because separate estimates for the private sectors reveal variation in height effects. Strong height wage premiums are paid in coal mining, wood processing, non ferrous metal industry, research and development while weak premiums were detected in aircraft and aerospace industry, iron and steel industry. It is difficult to give a plausible answer to these results. However, the outcome demonstrates that the average height in industries with weak effects is lower than the total average. Thus, the wage premium could be interpreted as an incentive to self-selection. 


\section{Summary}

The results of this paper demonstrate that there exists a strongly positive relationship between wages and body height in the univariate case. As height is also correlated with other earnings determinants a multivariate analysis seems necessary. Nevertheless, the height effect persists if important wage determinants are considered. Unobserved individual effects and measurement errors require methodological modifications. On the one hand, a new two-step panel estimator is applied where correlations between regressors and the individual term are allowed and time invariant influences can be considered. On the other hand, the height variable is substituted by instrumental variables. In the final estimates the height effect is not significant or the effect differs strongly from that of other estimates. Several explanations of this outcome lead to further investigations. Two new results follow: (1) The height effect is varying with a nonlinear trend. Furthermore cyclical movements were detected. The higher the lagged GDP growth rate the higher is the height effect on wages. During a recession the height premium is smaller or vanishes. Unobserved characteristics of tall people are less important. (2) Apart from the nonlinear trend the individual relationship between wages and height is also nonlinear. The maximal effect for men is evidently above the mean of the male height while the analogous maximal value for women is below the average female height. The preference for tall people is partially due to endowment and partially due to discrimination or unobserved productivity effects which differ between small and tall workers. For males the endowment effect is more important while for females we observe the opposite. In both cases discrimination seems to be effective. We find employer discrimination and less obviously customer discrimination. Altogether, there does not exist a simple, univariate link between height and wage but rather a complex network of influences that were detected. 


\section{References}

Amemiya, T. and T.E. MaCurdy (1986): Instrumental Variable Estimation of an Error Component Model, Econometrica 54, 869 - 880.

Averett, S. and S. Korenman (1996): The Economic Reality of the Beauty Myth, Journal of Human Resources 31, 304 - 330.

Baten, J. (1999): Ernährung und wirtschaftliche Entwicklung in Bayern (17301880), Beiträge zur Wirtschafts- und Sozialgeschichte, Bd. 82, Franz Steiner Verlag: Stuttgart.

Baten, J. (2000): Economic Development and the Distribution of Nutritional Resources in Bavaria, 1797-1839, Journal of Income Distribution 9, 89 - 106.

Behrman, J.R. and M.R. Rosenzweig (2001): The Returns to Increasing Body Weight, PIER Working Paper 01-052

Biddle, J.E. and D.S. Hamermesh (1998): Beauty, Productivity, and Discrimination: Laywer's Looks and Lucre, Journal of Labor Economics 16, 172 201.

Blinder, A. (1973): Wage Discrimination: Reduced Form and Structural Estimates, Journal of Human Resources 18, 436 - 455.

Cameron, A.C. and P.K. Trivedi (2005): Microeconometrics - Methods and Applications, Cambridge: University Press.

Cawley, J. (2004): The Impact of Obesity on Wages, Journal of Human Resources 39, $451-471$.

Cawley, J. and S. Danziger (2004): Obesity as a Barrier to the Transition from Welfare to Work, NBER Working Paper No. W10508.

Cleveland, W. (1979): Robust Locally Weighted Regression and Smoothing Scatterplots, Journal of the American Statistical Society 74, 829 - 836.

Conley, D. and R. Glauber (2005): Gender, Body Mass and Economic Status, NBER Working Paper No. W11343.

D'Hombres, B. and G. Brunello (2005): Does Obesity Hurt Your Wages More in Dublin than in Madrid? IZA Discussion Paper No. 1704.

Galbraith, J.K. (1985): The Anatomy of Power, Houghton Mifflin Company.

Galeotti, A. and G. Mueller (2005): Friendship Relations in the School Class and Adult Economic Attainment, IZA Discussion Paper No. 1682-

Galton, F. (1865): Hereditary Genius, its Laws and Consequences, London: MacMillan. 
Gladwell, M. (2005): Blink: The Power of Thinking without Thinking, New York: Little, Brown \& Company.

Haisken-DeNew, J. and J. Frick (2003): Desktop Companion to the German Socio-Economic Panel Study, DIW Berlin.

Hamermesh, D.S. and J.E. Biddle (1994): Beauty and the Labor Market, American Economic Review 84, 174 - 194.

Harper, B. (2000): Beauty, Stature And The Labour Market: A British Cohort Study, Oxford Bulletin of Economics and Statistics 62, 773 - 802.

Hausman, J.A. and W.E. Taylor (1981): Panel Data and Unobservable Individual Effects, Econometrica 49, 1377 - 1398.

Heckman, J.J. (1979): Sample Selection as a Specification Error, Econometrica $42,679-694$.

Heckman, J.J., Lochner, L. and P.E. Todd (2003): Fifty Years of Mincer Earnings Regressions, IZA Discussion Paper No. 775.

Heineck, G. (2005): Up in the Skies? The Relationship between Body Height and Earnings in Germany, Labour, 469 - 489.

Hübler, O. (1989): Ökonometrie, Stuttgart: Fischer-Verlag.

Hübler, O. (2003): Neuere Entwicklungen in der Mikroökonometrie, in: W. Franz, H.J. Ramser, M. Stadler (Hrsg.) Empirische Wirtschaftsforschung, Wirtschaftswissenschaftliches Seminar Ottobeuren, Bd. 32., Tübingen: Mohr Siebeck, $1-35$.

Hübler, O. (2006): Multilevel and Nonlinear Panel Data Models, Allgemeines Statistisches Archiv 90, 121 - 136..

Juhn, C., Murphy, K.M. and B. Pierce (1993): Wage Inequality and the Rise in Returns to Skill, Journal of Political Economy 101, 410 - 442.

Kennedy, E. and M. Garcia (1994): Body Mass Index and Economic Productivity, European Journal of Clinical Nutrition 48, Suppl., S45 - S53.

Komlos, J. and M. Baur (2003): From the Tallest to (One of) the Fattest: The Enigmatic Fate of the American Population in the 20th Century, CESifo Working Paper No. 1028.

Komlos, J. and P. Kriwy (2003): The Biological Standard of Living in the Two Germanies, German Economic Review 4, 459 - 473.

Kriwy, P., Komlos, J. and M. Baur (2003): Soziale Schicht und Körpergröße in Ost- und Westdeutschland, Kölner Zeitschrift für Soziologie und Sozialpsychologie 55 . 
Kuhn, P. and C. Weinberger (2005): Leadership Skills and Wages, Journal of Labor Economics 23, No. 3 (IZA Working Paper No. 482).

Mobius, M.M. and T.S. Rosenblat (2004): Why Beauty Matters? Mimeo, Wesleyan University.

Nettle, D. (2002): Women's Height, Reproductive Success and the Evolution of Sexual Dimorphism in Modern Humans, Proceedings of the Royal Society of London, B 269, 1919 - 1923.

Oerter, R. and E. Dreher (1995): Jugendalter, in: R. Oerter und L. Montada (Hrsg.), Entwicklungspsychologie, 3. Aufl., Weinheim: Beltz.

Ogden, C.L. (2004): Mean Body Weight, Height, and Body Mass Index United States 1960-2002, CDC Advance Data No. 347.

Persico, N., Postlewaite, A. and D. Silverman (2004): The Effect of Adolescent Experience on Labor Market Outcomes: The Case of Height, Journal of Political Economy 112, 1019 - 1053.

Rubenstein, M., Wissman, M. and C. Meyers (1998): Don't Want No Short, Short Man: The Study of Height, Power, and Mate Selection, Miami University.

Ryan, M.K. and S.A. Haslam (2005): The Glass Cliff: Evidence That Women are Over-represented in Precarious Leadership Positions, British Journal of Management 16, 81 - 90 .

Samaras, T.T., Elrick, H. and L.H. Storms (2003): Is Height Related to Longevity? Life Science 72, 1781 - 1802.

Samaras, T.T., Elrick, H. and L.H. Storms (2004): Is Short Height Really a Risk Factor for Coronary Heart Decease and Stroke Mortality? A Review, Medical Science Monitor 10, RA 63 - 76.

Samaras, T.T. and H. Elrick (2002): Less is Better, Journal of the National Medical Association 94, 88 - 99.

Schultz, T.P. (2002): Wage Gains Associated with Height as a Form of Health Human Capital, American Economic Review 92, Papers and Proceedings, 349 353.

Silbereisen, R.K. and E. Schmidt-Rodermund (1999): Prognostische Bedeutung von Unterschieden im Entwicklungstempo während der Pubertät, in: R. Oerter, C.v. Hagen, G. Röper und G. Noam (Hrsg.), Klinische Entwicklungspsychologie, Weinheim: Beltz.

Winkler, J. (1998): Die Messung des sozialen Status mit Hilfe eines Index in den Gesundheitssurveys der DHP, in: W. Ahrens, B.-M. Bellach and K-H. Jöckel (eds), Messung soziodemographischer Merkmale in der Epidemiologie, RKI-Schriften, München: MMV Medizin-Verlag. 